\title{
Analisis Penerimaan Bea Balik Nama Kendaraan Bermotor terhadap Penerimaan Pajak Daerah Provinsi DKI Jakarta
}

\author{
Fitri Rahmiyatun ${ }^{1}$, Eka Dyah Setyaningsih ${ }^{2}$, Nurul Hidayah ${ }^{3}$ \\ ${ }^{1,2}$ Univeristas Bina Sarana Informatika \\ e-mail:, ${ }^{1}$ fitri.frn@bsi.ac.id , ${ }^{2}$ eka.edy@bsi.ac.id, ${ }^{3}$ nurulhid74@gmail.com

\begin{tabular}{ccc}
\hline Diterima & Direvisi & Disetujui \\
$04-03-2020$ & $09-03-2020$ & $10-03-2020$ \\
\hline
\end{tabular}

\begin{abstract}
Abstrak - Kendaraan bermotor di Indonesia khususnya Jakarta setiap tahunnya mengalami peningkatan. Hal ini di dukung karena adanya kemudahan yang diberikan dealer dalam pembelian kendaraan bermotor yang mengakibatkan terjadinya perpindahan kepemilikan suatu kendaraan bermotor dan memicu pengenaan biaya balik nama. Bea Balik Nama Kendaraan Bermotor adalah penyerahan kendaraan bermotor karena perjanjian dua belah pihak atau sepihak atas jual beli atau warisan. Metode pengumpulan data menggunakan metode observasi, wawancara, dan studi dokumentasi dengan metode analisanya berupa metode kuantitatif sekunder. Berdasarkan data yang diolah bahwa Bea Balik Nama Kendaraan Bermotor sebagai variabel X dan Penerimaan Pajak Daerah Provinsi DKI Jakarta sebagai variabel Y terdapat hubungan signifikan yang kuat sebesar 0,615. Terdapat pengaruh signifikan antara Penerimaan Bea Balik Nama Kendaraan Bermotor Terhadap Pajak Daerah Provinsi DKI Jakarta sebesar 38\% dan 62\% disebabkan oleh faktor lainnya, serta persamaan regresi linier sederhana antara Penerimaan Bea Balik Nama Kendaraan Bermotor terhadap Pajak Daerah Provinsi DKI Jakarta yaitu Y = $20,939+0,285 X$
\end{abstract}

Kata Kunci :Penerimaan Bea Balik Nama Kendaran Bermotor

Abstract - Motor vehicles in Indonesia, especially Jakarta, are experiencing an increase every year. This is supported because of the convenience provided by dealers in the purchase of motor vehicles which results in the transfer of ownership of a motorized vehicle and triggers the imposition of transfer fees. Transfer of Motor Vehicle Title Fee is the surrender of a motorized vehicle because of the agreement of two parties or one party to a sale or inheritance. The data collection method uses the method of observation, interviews, and documentation studies with the method of analysis in the form of secondary quantitative methods. Based on the data that is processed that the Transfer of Motor Vehicle Title Fee as a variable X and the Regional Tax Revenue of the Province of DKI Jakarta as a variable Y there is a strong significant relationship of 0.615. There is a significant influence between Revenue Transfer Fees for Motorized Vehicles Against Regional Taxes of DKI Jakarta Province by $38 \%$ and $62 \%$ due to other factors, as well as the simple linear regression equation between Revenue Transfer Fees for Motorized Vehicles to Regional Taxes of DKI Jakarta Province, namely Y=20,939+ $0.285 X$

Keywords: Acceptance of Transfer Fees for Motorized Vehicles

\section{PENDAHULUAN}

Jumlah kendaraan bermotor di Jakarta mengalami peningkatan yang cukup tinggi. Berbagai kemudahan yang diberikan dealer dan dukungan perusahaan pembiayaan kendaraan bermotor memikat masyarakat untuk membeli, baik itu sebagai pemenuhan kebutuhan transportasi atau gaya hidup.

Selain mobil baru, masyarakat juga memiliki minat yang tinggi atas kendaraan bermotor bekas. Dukungan perusahaan pembiayaan untuk pembelian kendaraan bermotor bekas membuat bisnis mobil dan motor bekas menjadi besar. Masyarakat yang tidak mampu membeli mobil atau motor baru memiliki alternatif untuk merealisasikan impiannya. Komunitas pecinta mobil tua turut menyemarakkan bisnis ini. Memiliki kendaraan bermotor bukan saja kebutuhan tapi juga gaya hidup.

Maraknya jual beli kendaraan bermotor bekas mengakibatkan mudahnya terjadi perpindahan kepemilikan suatu kendaraan bermotor. Dari sisi pemerintah, maraknya bisnis kendaraan bermotor bekas menimbulkan potensi penerimaan baru, yaitu pengenaan Biaya Balik Nama Kendaraan Bermotor atau disingkat BBNKB.

BBNKB adalah pajak atas penyerahan hak milik kendaraan bermotor sebagai akibat perjanjian dua belah pihak atau perbuatan sepihak atau keadaan yang terjadi karena jual beli, tukar menukar, hibah, 
warisan, atau pemasukan kedalam badan usaha. Bea Balik Nama Kendaraan Bermotor telah diatur dalam UU Nomor 28 Tahun 2009 tentang Pajak Daerah dan Retribusi Daerah, pemerintah pusat mengalihkan

beberapa pajak yang semula ditarik oleh pusat menjadi pajak daerah. Selain itu, terdapat perluasan basis pajak yang sudah ada, yaitu Pajak Kendaraan Bermotor (PKB) dan Bea Balik Nama Kendaraan Bermotor (BBNKB) serta Peraturan Daerah Provinsi DKI Jakarta Nomor 9 Tahun 2010 tentang Bea Balik Nama Kendaraan Bermotor (BBNKB) yang dilengkapi dengan keputusan gubernur DKI Jakarta Nomor 210 Tahun 2015. Pembentukan UU No 32 Tahun 2004 Tentang Pemerintahan Daerah, merupakan suatu upaya untuk meningkatkan kualitas pelayanan pemerintah terhadap masyarakat, melalui sebuah kebijakan otonomi daerah.

Menurut penelitian terdahulu (Winarso,2015) adalah Penerimaan pajak kendaraan bermotor untuk tahun 2012 meningkat sebesar 47,8\%. Dan pencapaian target penerimaan pajak kendaraan bermotor secara keseluruhan pada tahun 2011 dan 2012 sudah melebihi dari yang sudah ditargetkan yakni sebesar $122,1 \%$ dan $122,2 \%$. Selain itu terdapat penelitian yang lainnya adalah ( Anggraini, Arisman, Yunita,2016) adalah Secara simultan terdapat pengaruh yang siginifikan antara Pajak Kendaraan Bermotor (PKB) dan Bea Balik Kendaraan Bermotor (BBNKB) terhadap Pendapatan Asli Daerah

di Provinsi Sumatera Selatan pada tahun 2012-2014, hal ini disebabkan oleh tingginya jumlah pertumbuhan kendaraan bermotor setiap tahunnya di Provinsi Sumatera Selatan yang berkelanjutan hingga pada periode penelitian ini.

Sebagai Ibukota Negara dan pusat bisnis utama di Indonesia, DKI Jakarta memiliki potensi BBNKB sangat besar. Berdasarkan data Samsat Jakarta Timur, penerimaan BBNKB tahun 2017 sebesar Rp 6.576.956.609.250. atau 5,55 persen dari total penerimaan pajak daerah DKI Jakarta yang tercatat Rp 36.499.698.888.571.

Berdasarkan latar belakang yang telah diuraikan sebelumnya maka rumusan masalah yang akan penulis kemukakan yaitu :

a. Apakah terdapat hubungan signifikan antara Penerimaan Bea Balik Nama Kendaraan Bermotor terhadap Penerimaan Pajak Daerah Provinsi DKI Jakarta?

b. Apakah terdapat pengaruh signifikan antara Penerimaan Bea Balik Nama Kendaraan Bermotor terhadap Penerimaan Pajak Daerah Provinsi DKI Jakarta?

c. Bagaimana persamaan regresi antara Penerimaan Bea Balik Nama Kendaraan Bermotor terhadap Penerimaan Pajak Daerah Provinsi DKI Jakarta?
Menurut Peraturan Daerah Nomor 9 Tahun 2010 dan Undang - Undang Nomor 28 Tahun 2009 Bea Balik Nama Kendaraan Bermotor adalah pajak atas penyerahan hak milik kendaraan bermotor sebagai akibat perjanjian dua pihak atau perbuatan sepihak atau keadaan terjadi karena jual beli, tukar menukar, hibah, warisan, atau pemasukan ke dalam badan usaha.

Menurut Perda Nomor 9 Tahun 2010 Dasar Pengenaan Bea Balik Nama Kendaraan Bermotor adalah sebagai berikut: Nilai Jual Kendaraan Bermotor. Nilai Jual Kendaraan Bermotor ditentukan berdasarkan Harga Pasaran Umum untuk kendaraan bermotor. Nilai Jual Kendaraan Bermotor ditetapkan berdasar Harga Pasaran Umum pada minggu pertama Bulan Desember Tahun Pajak sebelumnya. Harga Pasaran Umum adalah harga rata -rata dari berbagai sumber. Jika Harga Pasaran Umum suatu kendaraan bermotor tidak diketahui, Nilai Jual Kendaraan Bermotor dapat didasarkan dari sebagian atau seluruh faktor - faktor, yaitu: (1) Harga Kendaraan Motor dengan isi silinder dan/atau satuan tenaga yang sama; (2) Penggunaan Kendaraan Bermotor untuk umum atau pribadi; (3) Harga Kendaraan Bermotor dengan merek Kendaraan Bermotor yang sama; (4) Harga Kendaraan Bermotor dengan tahun pembuatan Kendaraan Bermotor yang sama; (5) Harga Kendaraan Bermotor dengan Kendaraan Bermotor sejenis; dan Harga Kendaraan Bermotor berdasarkan dokumen Pemberitahuan Impor Barang (PIB).

Sesuai Perda No.9 Tahun 2010 tentang Tarif Pajak Bea Balik Nama Kendaraan Bermotor (BBNKB) adalah:

Tarif Pajak Bea Balik Nama Kendaraan Bermotor ditetapkan paling tinggi sebesar $10 \%$ (sepuluh persen).

Khusus untuk Kendaraan Bermotor alat - alat berat dan alat besar yang tidak menggunakan jalan umum, tarif pajak yang ditetapkan masing-masing sebagai berikut: Penyerahan Kendaraan Bermotor alat - alat berat sebesar 0,75\% (nol koma tujuh lima); dan Penyerahan Kendaraan Bermotor alat besar dan seterusnya sebesar $0,075 \%$ (nol koma nol tujuh lima).

Sedang penyerahan karena warisan sebesar $0,1 \%$ untuk umum dan bukan umum dan $0,03 \%$ untuk alat berat dan alat - alat besar.

Menurut Peraturan Daerah Nomor 9 Tahun 2010 Subjek Pajak Bea Balik Kendaraan Bermotor adalah Orang pribadi; dan Badan yang menerima Kendaraan Bermotor tersebut. Adapun menurut Peraturan Daerah Nomor 9 Tahun 2010 Objek Pajak Bea Balik Nama Kendaraan Bermotor adalah:

Penyerahan kepemilikan Kendaraan Bermotor. Termasuk dalam pengertian kendaraan bermotor beroda beserta gandengannya, yang dioperasikan di semua jenis jalan darat, dan kendaraan Bermotor 
yang dioperasikan di air dengan ukuran isi kotor GT 5 (lima Gross Tonnage) sampai dengan GT 7 (tujuh Gross Tonnage).

Dikecualikan dari pengertian kendaraan bermotor adalah: Kereta api; Kendaraan Bermotor yang semata - mata digunakan untuk keperluan pertahanan dan keamanan negara; Kendaraan Bermotor yng dimiliki dan/atau dikuasai kedutaan, konsultan, perwakilan negara asing dengan asas timbal balik dan lembaga - lembaga internasional yang memperoleh fasilitas pembebasan pajak dan pemerintah; dan Kendaraan Bermotor yang dimiliki dan/atau dikuasai oleh pabrikan atau importir yang semata - mata disediakan untuk keperluan pameran dan tidak untuk dijual.

Termasuk penyerahan Kendaraan Bermotor meliputi: Penguasaan Kendaraan Bermotor melebihi 12 (dua belas) bulan dianggap sebagai penyerahan, kecuali penguasaan Kendaraan Bermotor karena perjanjian sewa beli. Pemasukan Kendaraan Bermotor dari luar negeri untuk dipakai secara tetap di Indonesia kecuali untuk; Dipakai sendiri oleh orang pribadi yang bersangkutan; Diperdagangkan; Dikeluarkan kembali dari wilayah pabean Indonesia; dan Dipergunakan untuk pameran, penelitian, contoh, dan kegiatan olahraga bertaraf internasional. Pengecualian tidak berlaku apabila selama 3 (tiga) tahun berturut - turut tidak dikeluarkan kembali dari wilayah Indonesia.

Menurut Peraturan Daerah Nomor 9 Tahun 2010 yang menjadi wajib pajak Bea Balik Nama Kendaraan Bermotor yaitu: Orang pribadi dan Badan.

Menurut UU No.28 Tahun 2009 cara perhitungan Bea Balik Nama Kendaraan Bermotor adalah sebagai berikut :

Besaran pokok BBNKB terutang dapat dihitung dengan rumus: $\mathrm{BBNKB}=$ Tarif $\mathrm{x}$ DPP

Untuk pembayaran dapat dilakukan pada saat pendaftaran di daerah tempat Kendaraan Bermotor terdaftar.

Menurut UU No.28 Tahun 2009 masa pajak Bea Balik Nama Kendaraan Bermotor adalah jangka waktu yang lamanya sama dengan jangka waktu penyerahan Kendaraan Bermotor pertama ke penyerahan berikutnya.

Menurut Peraturan Daerah Nomor 9 Tahun 2010 terutang Bea Balik Nama Kendaraan Bermotor pada saat penyerahan kendaraan bermotor.

Menurut (Ruma \& Jamal, 2013) menjelaskan bahwa: "Pembangunan nasional harus dilaksanakan merata di seluruh tanah air dan harus benar-benar dirasakan oleh seluruh rakyat sebagai perbaikan tingkat hidup yang berkeadilan sosial yang menjadi tujuan dan cita-cita kemerdekaan Indonesia." Agar tujuan tersebut tercapai maka baik Pemerintah dan warga negara harus digalang kerjasama dan hubungan timbal balik baik di segala aspek kehidupan, baik di bidang ekonomi, politik, hukum, sosial dan budaya.

Menurut UU No. 28 tahun 2009 tentang Pajak Daerah dan Retribusi, pasal 1 Ketentuan Umum butir 10, menyatakan bahwa: "Pajak daerah, yang selanjutnya disebut pajak, adalah kontribusi wajib kepada daerah yang terutang oleh orang pribadi atau badan yang bersifat memaksa berdasarkan Undang-Undang, dengan tidak mendapatkan imbalan secara dan digunakan untuk keperluan daerah bagi sebesar-besarnya kemakmuran rakyat".

Pengertian Pajak Daerah Menurut (Mardiasmo, 2016) menyatakan bahwa Iuran yang wajib dilakukan oleh masyarakat baik orang pribadi dan badan kepada daerah, yang tidak mendapatkan imbalan langsung, sifatnya dapat dipaksakan karena berdasarkan Undang-undang. Macam-macam pajak daerah antara lain: Bea Balik Nama Kendaraan Bermotor, Pajak Kendaraan Bermotor, Pajak Hiburan, Pajak Hotel, Pajak Sarang Burung Walet,Pajak Restoran, Pajak Reklame, Pajak Penerangan Jalan, Pajak Mineral Bukan Logam dan Batuan, Pajak Bea Perolehan Hak atas Tanah dan Bangunan, Pajak Air Tanah, dan Pajak Bumi dan Bangunan Pedesaan dan Perkotaan, Pajak Parkir.

Menurut UU No. 28 tahun 2009 dalam jurnal (Sabil, 2017) yang menjadi subjek pajak daerah adalah sebagai berikut:

Subjek Kendaraan Bermotor dan Kendaraan di Atas Air adalah orang pribadi atau badan yang menguasai dan/atau memiliki kendaraan bermotor; dan orang pribadi atau badan yang menerima penyerahan kendaraan bermotor.

Subjek Pajak Bahan Bakar Kendaraan Bermotor adalah konsumen bahan bakar kendaraan bermotor, baik orang pribadi atau badan yang menggunakan kendaraan bermotor.

Subjek Pajak Air Permukaan adalah orang pribadi atau badan yang melakukan mengambil dan atau memanfaatkan air permukaan. Subjek Pajak Hotel adalah orang pribadi atau badan yang melakukan pembayaran kepada hotel.

Subjek Pajak Restoran adalah orang pribadi atau badan yang melakukan pembayaran pajak restoran.

Subjek Pajak Hiburan adalah orang pribadi atau badan yang menonton dan/atau menikmati hiburan.

Subjek Pajak Reklame adalah orang pribadi atau badan yang melakukan pemesanan reklame. Wajib pajaknya adalah orang pribadi yang menyelenggarakan reklame.

Subjek Pajak Penerangan Jalan adalah orang pribadi atau badan yang menggunakan tenaga listrik.

Menurut UU No. 28 tahun 2009 dalam jurnal (Sabil, 2017) bagian dari objek pajak daerah adalah:

Objek Pajak Kendaraan Bermotor dan Kendaraan di Atas Air adalah kepemilikan dan/atau penguasaan Kendaraan Bermotor dan Kendaraan di 
Atas Air.

Objek Pajak Bahan Kendaraan Bermotor adalah Bahan Bakar Kendaraan Bermotor yang disediakan atau dianggap digunakan untuk Kendaraan Bermotor, termasuk bahan bakar yang digunakan untuk Kendaraan di Atas Air.

Objek Pajak Pengambilan dan Pemanfaatan Air Bawah Tanah dan Air Permukaan adalah:Pengambilah air bawah tanah dan/atau air permukaan; Pemanfaatan air bawah tanah dan/atau air permukaan; dan Pengambilan dan pemanfaatan air bawah tanah dan/atau air permukaan

Sedang objek pajak hotel yaitu pelayanan yang disediakan hotel dengan pembayaran termasuk: Fasilitas penginapan atau fasilitas tinggal jangka pendek; Pelayanan penunjang sebagai kelengkapan fasilitas penginapan atau tinggal jangka pendek yang sifatnya memberikan kemudahan dan kenyamanan; Jasa persewaan ruangan untuk kegiatan acara atau pertemuan di hotel.

Untuk objek pajak parkir yaitu semua penyelenggaraan tempat parkir diluar badan jalan, baik yang disediakan berkaitan dengan pokok usaha maupun yang disediakan sebagai suatu usaha, termasuk penyediaan tempat penitipan kendaraan bermotor dan garasi kendaraan bermotor yang memungut bayaran.

\section{METODOLOGI PENELITIAN}

Dasar perhitungan merupakan salah satu panduan yang digunakan oleh penulis untuk menganalisis data-data yang telah dikumpulkan untuk menjadi sebuah penelitian pada Tugas Akhir ini. Berdasarkan judul Tugas Akhir yang telah dikemukakan diatas yaitu "Analisis Penerimaan Bea Balik Nama Kendaraan Bermotor Terhadap Penerimaan Pajak Daerah Provinsi DKI Jakarta", maka variabel yang digunakan adalah:

1. Variabel Bebas / Independent Menurut (Dyah, 2017) "variabel independent atau variabel bebas sering disebut prediktor yaitu variabel yang mempengaruhi variabel lain". Variabel bebas (Variabel $\mathrm{X}$ ) dalam penelitian ini adalah Penerimaan Bea Balik Nama Kendaraan Bermotor.

2. Variabel Terikat/Dependent

Menurut (Dyah, 2017) variabel terikat merupakan variabel yang dipengaruhi variabel bebas. Variabel terikat (Variabel Y) dalam penelitian ini adalah Penerimaan Pajak Daerah Provinsi DKI Jakarta.

Untuk menghasilkan hasil penelitian yang akan diteliti maka penulis menggunakan beberapa pengujian yang dibantu oleh program aplikasi IBM SPSS Statistic Version 21.

\section{Uji Koefisien Korelasi}

Menurut (Sugiyono, 2016) Uji koefisien korelasi dilakukan untuk mengetahui hubungan antara dua variabel, dan jika terjadi hubungan, bagaimana arah hubungan tersebut apakah hubungan bersifat kuat atau tidak. Keeratan hubungan antara satu variable dengan variable yang lain biasa disebut dengan Koefisien Korelasi yang ditandai dengan " $r$ ".

Sedang menurut (Siregar, 2017) "korelasi merupakan angka yang menunjukkan tinggi atau rendahnya hubungan antara dua variabel atau lebih". Koefisien korelasi yang tinggi dapat diartikan bahwa besarnya hubungan antara kedua variabel. Besarnya koefisien korelasi berkisar -1 sampai +1 .

Jika nilai koefisien korelasi bernilai positif maka dapat disimpulkan bahwa apabila variabel yang satu meningkat maka variabel yang lainnya juga meningkat dan begitu sebaliknya apabila variabel yang satu turun maka variabel yang lainnya akan turun.

Jika nilai koefisien korelasi bernilai negatif akan memiliki arti bahwa apabila variabel yang satu naik maka variabel yang lain akan turun dan sebaliknya apabila variabel yang satu turun maka variabel yang lainnya akan naik. Saling berlawanan arah.

Berikut ini dikemukakan rumus yang dipergunakan untuk menghitung koefisien korelasi sederhana yaitu:

$$
r=\frac{n \Sigma x y-(\Sigma x)(\Sigma y)}{\sqrt{\left\{n \Sigma x^{2}-(\Sigma x)^{2}\right\}\left\{n \Sigma y^{2}-(\Sigma y)^{2}\right\}}}
$$

Dimana :

$\mathrm{n}=$ Penerimaan Bea Balik Nama Kendaraan Bermotor Dan Pajak Daerah Provinsi DKI Jakarta.

$\Sigma \mathrm{x}=$ Total jumlah dari Penerimaan Bea Balik Nama Kendaraan Bermotor.

$\Sigma y=$ Total jumlah dari Pajak Daerah Provinsi DKI Jakarta.

$\Sigma \mathrm{x} 2=$ Kuadrat dari total jumlah Penerimaan Bea Balik Nama Kendaraan Bermotor.

$\Sigma$ y2 $=$ Kuadrat dari total jumlah Pajak Daerah Provinsi DKI Jakarta.

$\Sigma x y=$ Hasil perkalian dari total jumlah Penerimaan Bea Balik Nama Kendaraan Bermotor dan Pajak Daerah Provinsi DKI Jakarta.

Tabel 1 Intreprestasi Koefisien Korelasi

\begin{tabular}{|c|c|}
\hline Interval Korelasi & Tingkat Hubungan \\
\hline $0,01-0,199$ & Sangat Rendah \\
\hline $0,20-0,399$ & Rendah \\
\hline $0.40-0,599$ & Sedang \\
\hline $0.60-0,799$ & Kuat \\
\hline $0,80-1,000$ & Sangat Kuat \\
\hline
\end{tabular}

Sumber : (Zulfikar \& Budiantara N, 2014)

Untuk koefisien korelasi tersebut terdapat:

$\mathrm{R}=0$ Hubungan $\mathrm{X}$ dan $\mathrm{Y}$ lemah sekali atau tidak ada hubungan

$\mathrm{R}=1$ Hubungan $\mathrm{X}$ dan $\mathrm{Y}$ sempurna dan positif

$\mathrm{R}=-1$ Hubungan $\mathrm{X}$ dan $\mathrm{Y}$ sempurna dan negatif 


\section{Uji Determinasi}

Menurut (Ghozali, 2016) tentang Koefisien determinasi $\left(\mathrm{R}^{2}\right)$ yaitu alat untuk mengukur kemampuan model/variabel dalam menerangkan variasi variabel dependen. Nilai koefisien determinasi sebesar antara 0 (nol) dengan 1 (satu). Nilai $\mathrm{R}^{\mathbf{2}}$ yang kecil berarti kemampuan variabel independen dalam menjelaskan variabel dependen amat terbatas. Nilai yang mendekati 1 (satu) berarti variabel independen memberikan hampir semua informasi yang dibutuhkan untuk memprediksi variasi variabel dependen.

Sedangkan menurut (Siregar, 2017) koefisien determinasi adalah angka yang menoefisien determinasi adalah angka yang menyatakan atau digunakan untuk mengetahui kontribusi atau sumbangan yang diberikan oleh sebuah variabel $\mathrm{x}$ (bebas) terhadap variabel y (terikat).

$\mathrm{Kd}=\mathrm{r} 2 \times 100 \%$

Keterangan :

$\mathrm{Kd}=$ koefisien determinasi

$\mathrm{r} 2=$ koefisien korelasi

Dimana pengaruh determinasi dapat diukur, jika :

$\mathrm{Kd}=0$, maka pengaruh Bea Balik Nama Kendaraan Bermotor terhadap Penerimaan Pajak Daerah Provinsi DKI Jakarta lemah.

$\mathrm{Kd}=1$, maka pengaruh Bea Balik Nama Kendaraan Bermotor terhadap Penerimaan Pajak Daerah Provinsi DKI Jakarta kuat.

\section{Uji Persamaan Regresi Linier Sederhana}

Menurut (Zulfikar \& Budiantara N, 2014) uji regresi linier sederhana digunakan untuk mencari pola hubungan fungsional antara satu variabel bebas dengan satu variabel terkait.

Sedangkan menurut (Ghozali, 2016) menyatakan bahwa "regresi sederhana didasarkan pada hubungan fungsional ataupun kasual satu variabel independen dengan satu variabel dependen".

Rumus persamaan tersebut yaitu:

$$
\mathrm{Y}=\mathrm{a}+\mathrm{bX}
$$

$\mathrm{Y}=$ Pajak Daerah Provinsi DKI Jakarta

$\mathrm{X}=$ Penerimaan Bea Balik Nama Kendaraan Bermotor.

$\mathrm{a}=$ Koefisien Konstanta.

$\mathrm{b}=$ Angka Koefisien Regresi.

\section{HASIL DAN PEMBAHASAN}

A. Data-Data

1. Data Penerimaan Bea Balik Nama Kendaraan Bermotor (BBNKB)

Berdasarkan data yang diterima penulis dari Samsat Jakarta Timur, jumlah Penerimaan Bea Balik
Nama Kendaraan Bermotor pada tahun 2015-2017 adalah sebagai berikut:

Tabel 2. Realisasi Penerimaan Bea Balik Nama Kendaraan Bermotor Tahun 2015 sampai dengan Tahun 2017 (X)

\begin{tabular}{|c|c|c|c|}
\hline BULAN & 2015 & 2016 & 2017 \\
\hline Januari & 86.351 .922 .300 & 72.858 .367 .800 & 86.201 .343 .600 \\
\hline Februari & 154.842 .483 .100 & 156.264 .522 .100 & 169.061 .679 .700 \\
\hline Maret & 233.252 .989 .700 & 243.130 .622 .200 & 259.467 .120 .200 \\
\hline April & 313.646 .514 .500 & 335.008 .371 .900 & 329.282 .533 .400 \\
\hline Mei & 392.318 .661 .200 & 419.791 .814 .900 & 418.164 .300 .200 \\
\hline Juni & 477.599 .925 .000 & 531.831 .463 .200 & 499.348 .157 .650 \\
\hline Juli & 548.940 .579 .600 & 586.895 .004 .000 & 575.369 .838 .550 \\
\hline Agustus & 617.913 .152 .700 & 687.619 .259 .100 & 672.073 .923 .550 \\
\hline September & 696.701 .829 .510 & 782.500 .546 .400 & 753.484 .911 .250 \\
\hline Oktober & 781.926 .145 .910 & 874.060 .175 .100 & 845.708 .162 .950 \\
\hline November & 858.852 .500 .110 & 91.136 .232 .000 & 938.205 .826 .250 \\
\hline Desember & 951.961 .014 .610 & 1.056 .851 .982 .400 & 1.030 .588 .811 .950 \\
\hline TOTAL & 6.114 .307 .718 .240 & 5.837 .948 .361 .100 & 6.576 .956 .609 .250 \\
\hline
\end{tabular}

Sumber : SAMSAT Jakarta Timur

Pada Realisasi Penerimaan Bea Balik Nama Kendaraan Bermotor Tahun 2015 sampai dengan Tahun 2017 (X) menunjukkan data variabel $\mathrm{X}$ atau realisasi Penerimaan Bea Balik Nama Kendaraan bermotor pada tahun 2015-2017 Tahun 2015 penerimaan sebesar Rp 6.114.307.718.240 di tahun 2016 mengalami penurunan penerimaan sebesar Rp 5.837.948.361.100 dan di tahun 2017 penerimaan mengalami peningkatan sebesar Rp 6.576.956.609.250.

\section{Data Penerimaan Pajak Daerah Provinsi DKI Jakarta}

Berdasarkan data yang diterima penulis dari Badan Pajak dan Retribusi Daerah Provinsi DKI Jakarta, Jumlah Penerimaan Pajak Daerah Provinsi DKI Jakarta pada tahun 2015-2017 adalah sebagai berikut:

Tabel 3 Realisasi Penerimaan Pajak Daerah Provinsi DKI Jakarta Tahun 2015 sampai dengan 2017 (Y)

\begin{tabular}{|l|l|l|l|}
\hline $\begin{array}{c}\text { BULA } \\
\mathrm{N}\end{array}$ & \multicolumn{1}{|c|}{2015} & \multicolumn{1}{c|}{2016} & \multicolumn{1}{c|}{2017} \\
\hline & & & \\
& 1.561 .057 .63 & 1.583 .587 .91 & 1.764 .143 .06 \\
Januari & 8.891 & 3.851 & 9.527 \\
\hline & & & \\
Februa & 1.450 .730 .69 & 1.845 .657 .67 & 2.166 .431 .32 \\
ri & 3.434 & 5.881 & 5.655 \\
\hline Maret & & & \\
\hline
\end{tabular}




\begin{tabular}{|c|c|c|c|}
\hline & $\begin{array}{l}1.857 .359 .90 \\
5.276\end{array}$ & $\begin{array}{l}1.918 .639 .37 \\
6.826\end{array}$ & $\begin{array}{l}2.299 .456 .79 \\
2.439\end{array}$ \\
\hline April & $\begin{array}{l}1.884 .859 .21 \\
9.730\end{array}$ & $\begin{array}{l}2.446 .926 .91 \\
2.603\end{array}$ & $\begin{array}{l}2.047 .189 .45 \\
4.759\end{array}$ \\
\hline Mei & $\begin{array}{l}2.006 .859 .21 \\
2.975 \\
\end{array}$ & $\begin{array}{l}2.187 .196 .01 \\
2.476\end{array}$ & $\begin{array}{l}2.791 .553 .23 \\
8.437\end{array}$ \\
\hline Juni & $\begin{array}{l}2.248 .456 .50 \\
3.437\end{array}$ & $\begin{array}{l}2.551 .732 .24 \\
2.131\end{array}$ & $\begin{array}{l}2.101 .484 .98 \\
4.859\end{array}$ \\
\hline Juli & $\begin{array}{l}2.020 .301 .69 \\
0.697\end{array}$ & $\begin{array}{l}1.847 .607 .34 \\
0.233\end{array}$ & $\begin{array}{l}2.982 .318 .01 \\
3.091\end{array}$ \\
\hline $\begin{array}{l}\text { Agustu } \\
\mathrm{s}\end{array}$ & $\begin{array}{l}5.178 .865 .62 \\
6.526\end{array}$ & $\begin{array}{l}6.287 .795 .96 \\
9.860\end{array}$ & $\begin{array}{l}6.811 .309 .81 \\
5.164\end{array}$ \\
\hline $\begin{array}{l}\text { Septem } \\
\text { ber }\end{array}$ & $\begin{array}{l}3.069 .323 .06 \\
0.532\end{array}$ & $\begin{array}{l}2.836 .563 .18 \\
7.605\end{array}$ & $\begin{array}{l}4.000 .137 .31 \\
4.070\end{array}$ \\
\hline $\begin{array}{l}\text { Oktobe } \\
\mathrm{r}\end{array}$ & $\begin{array}{l}2.390 .503 .67 \\
1.421\end{array}$ & $\begin{array}{l}2.555 .015 .64 \\
0.940\end{array}$ & $\begin{array}{l}2.968 .502 .39 \\
7.417\end{array}$ \\
\hline $\begin{array}{l}\text { Novem } \\
\text { ber }\end{array}$ & $\begin{array}{l}2.171 .265 .86 \\
6.149\end{array}$ & $\begin{array}{l}2.415 .023 .00 \\
4.827\end{array}$ & $\begin{array}{l}2.923 .487 .23 \\
6.582\end{array}$ \\
\hline $\begin{array}{l}\text { Desem } \\
\text { ber }\end{array}$ & $\begin{array}{l}3.237 .854 .31 \\
3.658\end{array}$ & $\begin{array}{l}3.040 .206 .46 \\
5.795\end{array}$ & $\begin{array}{l}3.643 .685 .24 \\
6.571\end{array}$ \\
\hline $\begin{array}{c}\text { TOTA } \\
\text { L }\end{array}$ & $\begin{array}{c}29.077 .437 .4 \\
02.727\end{array}$ & $\begin{array}{c}31.515 .951 .7 \\
43.028\end{array}$ & $\begin{array}{c}36.499 .698 .8 \\
88.571\end{array}$ \\
\hline
\end{tabular}

Sumber : Badan Pajak dan Retribusi Daerah Provinsi DKI Jakarta

Pada Realisasi Penerimaan Pajak Daerah Provinsi DKI Jakarta Tahun 2015 sampai dengan 2017 menunjukkan data variabel Y atau Realisasi Penerimaan Pajak Daerah Provinsi DKI Jakarta pada tahun 2015-2017 mengalami peningkatan tahun. Untuk memudahkan pengujian dan analisis data maka penulis menyederhanakan data Penerimaan Bea Balik Nama Kendaraan Bermotor (X) maupun Penerimaan Pajak Daerah Provinsi DKI Jakarta (Y) dengan menggunakan cara Logaritma Natural (LN) pada Microsoft Excel, sebagai berikut:

Tabel 4 Variabel X dan Y yang telah disederhanakan

\begin{tabular}{|c|c|c|c|c|c|}
\hline \multicolumn{3}{|c|}{ X } & \multicolumn{3}{c|}{$Y$} \\
\hline 2015 & 2016 & 2017 & 2015 & 2016 & 2017 \\
\hline 25,18 & 25,01 & 25,18 & 28,08 & 28,09 & 28,20 \\
\hline 25,77 & 25,77 & 25,85 & 28,00 & 28,24 & 28,40 \\
\hline 26,18 & 26,22 & 26,28 & 28,25 & 28,28 & 28,46 \\
\hline 26,47 & 26,54 & 26,52 & 28,26 & 28,53 & 28,35 \\
\hline 26,70 & 26,76 & 26,76 & 28,33 & 28,41 & 28,66 \\
\hline 26,89 & 27,00 & 26,94 & 28,44 & 28,57 & 28,37 \\
\hline 27,03 & 27,10 & 27,08 & 28,33 & 28,24 & 28,72 \\
\hline 27,15 & 27,26 & 27,23 & 29,28 & 29,47 & 29,55 \\
\hline 27,27 & 27,39 & 27,35 & 28,75 & 28,67 & 29,02 \\
\hline
\end{tabular}

\begin{tabular}{|l|l|l|l|l|l|}
27,39 & 27,50 & 27,46 & 28,50 & 28,57 & 28,72 \\
\hline 27,48 & 25,24 & 27,57 & 28,41 & 28,51 & 28,70 \\
\hline 27,58 & 27,69 & 27,66 & 28,81 & 28,74 & 28,92 \\
\hline
\end{tabular}

Sumber : Data diolah dengan Microsoft Excel

\section{Tabel Penolong}

Berikut adalah ringkasan tabel penolong pada untuk analisis data baik secara manual maupun menggunakan program aplikasi IBM SPSS versi 21.

Tabel 5 Tabel Penolong

\begin{tabular}{|c|c|c|c|c|c|}
\hline \multirow{2}{*}{$\begin{array}{l}\text { TAHU } \\
\mathrm{N}\end{array}$} & & $\mathrm{LN}$ & \multirow[t]{2}{*}{$\mathrm{X} 2$} & \multirow[t]{2}{*}{ Y2 } & \multirow[t]{2}{*}{$\mathrm{XY}$} \\
\hline & $X$ & $\mathrm{Y}$ & & & \\
\hline \multirow{12}{*}{2015} & 25,18 & 28,08 & 634,12 & 788,28 & 707,01 \\
\hline & 25,77 & 28,00 & 663,87 & 784,17 & 721,52 \\
\hline & 26,18 & 28,25 & 685,15 & 798,07 & 739,46 \\
\hline & 26,47 & 28,26 & 700,74 & 798,90 & 748,21 \\
\hline & 26,70 & 28,33 & 712,64 & 802,45 & 756,21 \\
\hline & 26,89 & 28,44 & 723,18 & 808,91 & 764,84 \\
\hline & 27,03 & 28,33 & 730,69 & 802,83 & 765,91 \\
\hline & 27,15 & 29,28 & 737,10 & 857,06 & 794,82 \\
\hline & 27,27 & 28,75 & 743,63 & 826,70 & 784,07 \\
\hline & 27,39 & 28,50 & 749,94 & 812,39 & 780,54 \\
\hline & 27,48 & 28,41 & 755,09 & 806,92 & 780,57 \\
\hline & 27,58 & 28,81 & 760,76 & 829,78 & 794,52 \\
\hline \multirow{12}{*}{2016} & 25,01 & 28,09 & 625,59 & 789,09 & 702,60 \\
\hline & 25,77 & 28,24 & 664,34 & 797,72 & 727,98 \\
\hline & 26,22 & 28,28 & 687,32 & 799,91 & 741,48 \\
\hline & 26,54 & 28,53 & 704,23 & 813,72 & 757,00 \\
\hline & 26,76 & 28,41 & 716,26 & 807,34 & 760,43 \\
\hline & 27,00 & 28,57 & 728,98 & 816,12 & 771,32 \\
\hline & 27,10 & 28,24 & 734,31 & 797,78 & 765,38 \\
\hline & 27,26 & 29,47 & 742,92 & 868,46 & 803,24 \\
\hline & 27,39 & 28,67 & 749,98 & 822,18 & 785,25 \\
\hline & 27,50 & 28,57 & 756,05 & 816,19 & 785,55 \\
\hline & 25,24 & 28,51 & 636,84 & 812,98 & 719,54 \\
\hline & 27,69 & 28,74 & 766,53 & 826,16 & 795,79 \\
\hline \multirow{9}{*}{2017} & 25,18 & 28,20 & 634,03 & 795,17 & 710,04 \\
\hline & 25,85 & 28,40 & 668,40 & 806,79 & 734,35 \\
\hline & 26,28 & 28,46 & 690,74 & 810,18 & 748,08 \\
\hline & 26,52 & 28,35 & 703,32 & 803,58 & 751,78 \\
\hline & 26,76 & 28,66 & 716,05 & 821,26 & 766,85 \\
\hline & 26,94 & 28,37 & 725,58 & 805,06 & 764,29 \\
\hline & 27,08 & 28,72 & 733,23 & 825,05 & 777,79 \\
\hline & 27,23 & 29,55 & 741,67 & 873,18 & 804,74 \\
\hline & 27,35 & 29,02 & 747,91 & 842,01 & 793,57 \\
\hline
\end{tabular}




\begin{tabular}{|c|c|c|c|c|c|} 
& 27,46 & 28,72 & 754,24 & 824,79 & 788,72 \\
\cline { 2 - 6 } & 27,57 & 28,70 & 759,95 & 823,91 & 791,28 \\
\cline { 2 - 6 } & 27,66 & 28,92 & 765,14 & 836,60 & 800,07 \\
\hline \multirow{2}{*}{ TOTAL } & $\begin{array}{c}962,4 \\
2\end{array}$ & $\begin{array}{c}1027,8 \\
6\end{array}$ & $\begin{array}{c}25750,5 \\
3\end{array}$ & $\begin{array}{c}29351,6 \\
8\end{array}$ & $\begin{array}{c}27484,8 \\
3\end{array}$ \\
\hline
\end{tabular}

Sumber : Data diolah dengan Microsoft Excel

\section{B. Analisis Penerimaan Bea Balik Nama Kendaraan Bermotor (X) Terhadap Penerimaan Pajak Daerah Provinsi DKI Jakarta (Y)}

Dalam penelitian ini analisis yang digunakan untuk mengetahui pengaruh variabel bebas (X) terhadap variabel terikat $(\mathrm{Y})$ dengan uji korelasi yaitu product moment person, uji koefisien determinasi, dan persamaan regresi yaitu uji regresi linier sederhana. Untuk memudahkan peneliti mengolah data penelitian serta menganalisis data tersebut, penulis menggunakan program aplikasi IBM SPSS Statistic Version 21

\section{Uji Koefisien Korelasi}

Uji koefisien korelasi digunakan untuk mengetahui kuat atau lemahnya hubungan signifikan antara Penerimaan Bea Balik Nama Kendaraan Bermotor terhadap Pajak Daerah Provinsi DKI Jakarta. Hipotesisnya sebagai berikut:

H0: Tidak terdapat hubungan signifikan antara Penerimaan Bea Balik Nama Kendaraan Bermotor (X) terhadap Pajak Daerah Provinsi DKI Jakarta (Y).

H1 : Terdapat hubungan signifikan antara Penerimaan Bea Balik Nama Kendaraan Bermotor (X) terhadap Pajak Daerah Provinsi DKI Jakarta (Y).

\section{a. Uji manual}

Berdasarkan pengolahan data secara manual, maka hasil uji koefisien korelasi sebagai berikut:

$$
\begin{aligned}
& r=\frac{n \Sigma x y-(\Sigma x)(\Sigma y)}{\sqrt{\left\{n \Sigma x^{2}-(\Sigma x)^{2}\right\}\left\{n \Sigma y^{2}-(\Sigma y)^{2}\right\}}} \\
& r=\frac{36(27.484,83)-(962,42) x(1,027,86)}{\sqrt{\left\{36(25.750,53)-(962,42)^{2}\right\}\left\{36(29.351,68)-(1.027,86)^{2}\right\}}} \\
& r=\frac{989.453,88-989.233,0212}{\sqrt{766,82 \times 164,300}} \\
& r=\frac{220,85}{27,69 \times 12,81} \\
& r=\frac{220,85}{354,70} \\
& r=0,622
\end{aligned}
$$

\begin{tabular}{|c|c|c|c|}
\hline & & $\begin{array}{c}\text { Bea Balik } \\
\text { Nama } \\
\text { Kendaraa } \\
n \\
\text { Bermotor }\end{array}$ & $\begin{array}{c}\text { Pajak } \\
\text { Daerah } \\
\text { Provinsi } \\
\text { DKI } \\
\text { Jakarta }\end{array}$ \\
\hline \multirow{3}{*}{$\begin{array}{l}\text { Bea Balik } \\
\text { Nama } \\
\text { Kendaraan } \\
\text { Bermotor }\end{array}$} & $\begin{array}{l}\text { Pearson } \\
\text { Correlation }\end{array}$ & 1 &, $615^{* *}$ \\
\hline & Sig. (1-tailed) & & ,000 \\
\hline & $\mathrm{N}$ & 36 & 36 \\
\hline \multirow{3}{*}{$\begin{array}{l}\text { Pajak } \\
\text { Daerah } \\
\text { Provinsi } \\
\text { DKI } \\
\text { Jakarta }\end{array}$} & $\begin{array}{l}\text { Pearson } \\
\text { Correlation }\end{array}$ &, $615^{* * 4}$ & 1 \\
\hline & Sig. (1-tailed) & ,000 & \\
\hline & $\mathrm{N}$ & 36 & 36 \\
\hline
\end{tabular}

b. Perhitungan Statistikal Product \& Service Solutions (SPSS) Versi 21
Tabel 5 Hasil Uji Koefisien Korelasi

Sumber : Hasil pengolahan data SPSS Versi 21

c. Dasar pengambilan keputusan sebagai berikut:

1) Apabila nilai $\mathrm{Sig}>0,05$ artinya tidak ada hubungan signifikan antara Penerimaan Bea Balik Nama Kendaraan Bermotor (X) terhadap Pajak Daerah Provinsi DKI Jakarta (Y)

2) Apabila nilai $\mathrm{Sig}<0,05$ artinya ada hubungan signifikan antara Penerimaan Bea Balik Nama Kendaraan Bermotor (X) terhadap Pajak Daerah Provinsi DKI Jakarta (Y)

\section{d. Hasil uji SPSS}

Pada Hasil Uji Koefisien Korelasi menunjukkan besarnya hubungan antara variabel Penerimaan Bea Balik Nama Kendaraan Bermotor dengan Penerimaan Pajak Daerah Provinsi DKI Jakarta yang dihitung menggunakan koefisien korelasi adalah 0,615. Hal ini menunjukkan hubungan yang kuat berdasarkan nilai SPSS sesuai dengan tabel interpretasi korelasi. Arah hubungan antara kedua variabel yang berarti tingkat korelasi searah dan menunjukkan semakin besar Penerimaan Bea Balik Nama Kendaraan Bermotor maka semakin cenderung meningkat Penerimaan Pajak Daerah Provinsi DKI Jakarta.

Demikian pula sebaliknya semakin kecil Penerimaan Bea Balik Nama Kendaraan Bermotor maka Penerimaan Pajak Daerah Provinsi DKI Jakarta semakin kecil pula.

\section{e. Kesimpulan H0 dan H1}

Tingkat signifikan koefisien dari output sig (1tailed) diukur dari probabilitas menghasilkan angka 0,000 . Karena probabilitas jauh dibawah $0,05(0,000<0,05)$ maka $\mathrm{H} 0$ ditolak dan $\mathrm{H} 1$ diterima yang berarti terdapat hubungan signifikan dan kuat antara Penerimaan Bea Balik Nama Kendaraan Bermotor $(\mathrm{X})$ dengan Penerimaan Pajak Daerah Provinsi DKI Jakarta (Y) sebesar 0,615 .

\section{Uji Koefisien Determinasi}

Uji determinasi digunakan untuk mengetahui 
pengaruh Penerimaan Bea Balik Nama Kendaraan Bermotor (X) mempengaruhi Pajak Daerah Provinsi DKI Jakarta (Y). Berdasarkan data yang telah diolah dalam uji koefisien korelasi ini, penulis menentukan hipotesis sebagai berikut:

H0 : Tidak Terdapat pengaruh signifikan antara Penerimaan Bea Balik Nama Kendaraan Bermotor (X) terhadap Pajak Daerah Provinsi DKI Jakarta (Y).

$\mathrm{H} 2$ : terdapat pengaruh signifikan antara Penerimaan Bea Balik Nama

Kendaraan Bermotor (X) terhadap Pajak Daerah Provinsi DKI Jakarta (Y).

\section{a. Uji manual}

Berdasarkan pengolahan data manual, maka hasil uji koefisien determinasi dapat dilihat sebagai berikut:

$$
\begin{aligned}
& \mathrm{KD}=\mathrm{R} 2 \times 100 \% \\
& \mathrm{KD}=(0,615) 2 \times 100 \% \\
& \mathrm{KD}=0,378 \times 100 \% \\
& \mathrm{KD}=37,8 \%
\end{aligned}
$$

\section{b. Perhitungan Statistikal Product \& Service} Solutions (SPSS) Versi 21

\begin{tabular}{|c|c|c|c|c|c|c|c|c|c|}
\hline \multirow{2}{*}{$\begin{array}{l}\text { Mo } \\
\text { del }\end{array}$} & \multirow[t]{2}{*}{$\mathrm{R}$} & \multirow{2}{*}{$\begin{array}{c}\mathrm{R} \\
\text { Squ } \\
\text { are }\end{array}$} & \multirow{2}{*}{$\begin{array}{c}\text { Adj } \\
\text { ust } \\
\text { ed } \\
\text { R } \\
\text { Squ } \\
\text { are }\end{array}$} & \multirow[b]{2}{*}{$\begin{array}{c}\text { Std } \\
\text { Err } \\
\text { or } \\
\text { of } \\
\text { the } \\
\text { Esti } \\
\text { mat } \\
\text { e }\end{array}$} & \multicolumn{5}{|c|}{ Change Statistics } \\
\hline & & & & & $\begin{array}{c}\mathrm{R} \\
\text { Squar } \\
\mathrm{e} \\
\text { Chan } \\
\text { ge }\end{array}$ & \begin{tabular}{|c}
$\mathrm{F}$ \\
$\mathrm{Ch}$ \\
ang \\
$\mathrm{e}$
\end{tabular} & df1 & df2 & $\begin{array}{l}\text { Sig. } \\
\text { F } \\
\text { Chan } \\
\text { ge }\end{array}$ \\
\hline & $\begin{array}{r}, 61 \\
5^{\mathrm{a}}\end{array}$ & $\begin{array}{r}, 37 \\
8\end{array}$ & $\begin{array}{r}, 36 \\
0\end{array}$ & $\begin{array}{r}, 28 \\
825\end{array}$ & ,378 & $\begin{array}{l}0, \\
48\end{array}$ & 1 & 34 & ,000 \\
\hline
\end{tabular}

Hasil menggunakan IBM SPSS Versi 21 pada tabel 6 sebagai berikut:

Tabel 6 Hasil Uji Koefisien Determinasi

a. Predictors: (Constant), Bea Balik Nama Kendaraan Bermotor

Sumber: Hasil Pengolahan Data SPSS Versi 21

c. Dasar pengambilan keputusan yaitu :

1) Apabila nilai Sig $>0,05$ artinya tidak ada pengaruh antara Penerimaan Bea Balik Nama Kendaraan Bermotor (X) terhadap Pajak Daerah Provinsi DKI Jakarta (Y)

2) Apabila nilai $\mathrm{Sig}<0,05$ artinya ada pengaruh antara Penerimaan Bea Balik Nama Kendaraan Bermotor (X) terhadap Pajak Daerah Provinsi DKI Jakarta (Y)

\section{d. Hasil uji SPSS}

Pada tabel III.6 diatas diketahui bahwa R Square yang diperoleh sebesar 0,378 yang dalam hal ini berarti pengaruh Penerimaan Bea Balik Nama Kendaraan Bermotor terhadap Penerimaan Pajak Daerah Provinsi DKI Jakarta sebesar 37,8\%. Sedangkan sisanya $62,2 \%$ dijelaskan oleh faktor- faktor lain yang tidak diteliti.

\section{e. Kesimpulan H0 dan $\mathrm{H} 2$}

Tingkat pengaruh signifikan dari output Sig. F Change diukur dari probabilitas menghasilkan angka 0,000 . Karena probabilitas jauh dibawah $0,05(0,000<0,05)$ maka H0 ditolak dan H2 diterima yang berarti terdapat pengaruh antara Penerimaan Bea Balik Nama Kendaraan Bermotor (X) dengan Penerimaan Pajak Daerah Provinsi DKI Jakarta (Y) sebesar 0,378.

\section{Uji Persamaan Regresi}

Untuk memprediksi seberapa jauh perubahan nilai efisien kinerja apabila nilai pengelolaan kearsipan diubah, maka digunakan uji persamaan persamaan regresi. Dalam penulisan Tugas Akhir penulis ingin menguji hipotesis sebagai berikut:

\section{a. Hipotesis}

Dalam Uji Persamaan Regresi, penulis menentukan Hipotesis sebagai berikut:

HO : Tidak terdapat persamaan regresi antara Penerimaan Bea Balik Nama Kendaraan Bermotor $(\mathrm{X})$ terhadap penerimaan pajak daerah provinsi DKI Jakarta (Y).

H3 : Terdapat persamaan regresi antara Penerimaan Bea Balik Nama Kendaraan Bermotor (X) terhadap Pajak Daerah Provinsi DKI Jakarta (Y).

\section{b. Uji manual}

$$
\begin{aligned}
& \mathrm{Y}=\mathrm{a}+6 \mathrm{X} \\
& \mathrm{b}=\frac{\mathrm{n} \sum \mathrm{XY}-\sum \mathrm{X} \sum \mathrm{Y}}{\mathrm{n} \sum \mathrm{X}^{2}-\left(\sum \mathrm{X}\right)^{2}} \\
& \mathrm{a}=\frac{\sum \mathrm{Y}-\mathrm{b} \cdot \sum \mathrm{X}}{\mathrm{n}}
\end{aligned}
$$

1) Mencari nilai $b$

$$
\begin{aligned}
& \mathrm{b}=\frac{\mathrm{n} \sum \mathrm{XY}-\sum \mathrm{X} \sum \mathrm{Y}}{\mathrm{n} \sum \mathrm{X}^{2}-\left(\sum \mathrm{X}\right)^{2}} \\
& \mathrm{~b}=\frac{36(27.484,83)-962,42 \times 1.027,86}{36(25.750,53)-(962,42)^{2}} \\
& \mathrm{~b}=\frac{989.453,88-989.233,021}{927.019,08-926.252,256} \\
& \mathrm{~b}=\frac{220,859}{766,824} \\
& \mathrm{~b}=0,288
\end{aligned}
$$

2) Mencari a

$$
\begin{aligned}
& \mathrm{a}=\frac{\sum \mathrm{Y}-\mathrm{b} \cdot \sum \mathrm{X}}{\mathrm{n}} \\
& \mathrm{a}=\frac{1.027,86-0,288 \times 962,42}{36}
\end{aligned}
$$




$$
\begin{aligned}
& a=\frac{1.027,86-277,176}{36} \\
& a=\frac{750,684}{36} \\
& a=20,852
\end{aligned}
$$

Dari perhitungan tersebut, persamaan regresi linier yang terbentuk adalah $\mathrm{Y}=20,852+0,288 \mathrm{X}$, hasil tersebut sama dengan perhitungan IBM SPSS versi 21 yang akan dijelaskan pada pembahasan pada tabel 7 .

\section{c. Perhitungan Statistikal Product \& Service Solutions (SPSS) Versi 21}

Tabel 7

Hasil Uji Persamaan Regresi ANOVA ${ }^{\mathrm{a}}$

\begin{tabular}{|l|r|r|r|r|r|}
\hline Model & $\begin{array}{l}\text { Sum of } \\
\text { Squares }\end{array}$ & Df & $\begin{array}{c}\text { Mean } \\
\text { Square }\end{array}$ & F & $\begin{array}{c}\text { Sig } \\
.\end{array}$ \\
\hline $\begin{array}{l}\text { Regressi } \\
\text { on }\end{array}$ & 1,716 & 1 & 1,716 & $\begin{array}{r}20,64 \\
8\end{array}$ & $\begin{array}{r}0^{0} \\
0^{\mathrm{b}}\end{array}$ \\
\hline 1 Residual & 2,825 & 34 &, 083 & & \\
\hline Total & 4,541 & 35 & & & \\
\hline
\end{tabular}

\begin{tabular}{|c|c|c|c|c|c|c|}
\hline \multicolumn{7}{|c|}{ Coefficients $^{\mathrm{a}}$} \\
\hline \multirow{2}{*}{\multicolumn{2}{|c|}{ Model }} & \multicolumn{2}{|c|}{$\begin{array}{c}\text { Unstandardiz } \\
\text { ed } \\
\text { Coefficients }\end{array}$} & $\begin{array}{c}\text { Standardi } \\
\text { zed } \\
\text { Coefficie }\end{array}$ & \multirow[t]{2}{*}{$\mathrm{t}$} & \multirow[t]{2}{*}{$\begin{array}{c}\text { Sig } \\
\text {. }\end{array}$} \\
\hline & & $\bar{B}$ & $\begin{array}{l}\text { Std. } \\
\text { Error }\end{array}$ & Beta & & \\
\hline & $\begin{array}{l}\text { (Constant } \\
\text { ) }\end{array}$ & $\begin{array}{r}20,93 \\
9\end{array}$ & 1,676 & & $\begin{array}{r}12,49 \\
5\end{array}$ & $\begin{array}{r}, 00 \\
0\end{array}$ \\
\hline 1 & $\begin{array}{l}\text { Bea Balik } \\
\text { Nama } \\
\text { Kendaraa } \\
\mathrm{n} \\
\text { Bermotor }\end{array}$ &, 285 & ,063 &, 615 & 4,544 & $\begin{array}{r}, 00 \\
0\end{array}$ \\
\hline
\end{tabular}

Dependent Variable $\quad$ : Pajak Daerah Provinsi DKI Jakarta Predictors (Constant) : Bea Balik Nama Kendaraan Bermotor

Dependent Variable: Pajak Daerah DKI Jakarta

Sumber: Hasil Pengolahan Data SPSS Versi 21

d. Dasar pengambilan keputusan sebagai berikut:

1) Apabila nilai $\mathrm{Sig}>0,05$ artinya tidak ada persamaan regresi antara Penerimaan Bea Balik Nama Kendaraan Bermotor (X) terhadap Pajak Daerah Provinsi DKI Jakarta (Y)

2) Apabila nilai $\mathrm{Sig}<0,05$ artinya ada persamaan regresi antara Penerimaan Bea Balik Nama Kendaraan Bermotor (X) terhadap Pajak Daerah Provinsi DKI Jakarta (Y)

\section{e. Hasil uji SPSS}

Hasil Uji Persamaan Regresi ANOVAa diketahui nilai konstanta a sebesar 20,939 dan nilai koefisien 6 adalah 0,285, maka dapat diperoleh bentuk persamaan regresi linier sederhana yaitu Y $=20,939+0,285 \mathrm{X}$

\section{f. Kesimpulan $\mathrm{H}_{0}$ dan $\mathrm{H}_{3}$}

Tingkat signifikan persamaan regresi linier sederhana dari output sig.((1-tailed) diukur dari probabilitas menghasilkan angka 0,000. Karena probabilitas jauh dibawah $0,05(0,000<0,05)$ maka H0 ditolak dan H3 diterima yang berarti terdapat persamaan Regresi yang signifikan antara Penerimaan Bea Balik Nama Kendaraan Bermotor (X) dengan Pajak Daerah Provinsi DKI Jakarta $(Y)$ sebesar $Y=20,939+0,285 X$.

\section{g. Kesimpulan}

Persamaan yang terbentuk dari hasil uji regresi linier sederhana menggunakan IBM SPSS versi 21 sama dengan persamaan yang didapat oleh penulis berdasarkan perhitungan manual yang sudah dibahas pada pembahasan sebelumnya. Pada persamaan regresi dapat ditarik kesimpulan berikut:

Nilai konstanta $\alpha=20,939$ dapat diartikan Penerimaan Bea Balik Nama Kendaraan Bermotor (X) nilainya nol (0), maka tingkat Pajak Daerah Provinsi DKI Jakarta (Y) adalah 20,939. Nilai koefisien 6 sebesar 0,285 dapat diartikan jika setiap peningkatan persepsi Penerimaan Bea Balik Nama Kendaraan Bermotor (X) sebesar satu (1), maka tingkat Pajak Daerah Provinsi DKI Jakarta (Y) akan meningkat 0,285 .

\section{KESIMPULAN}

Dengan hasil penelitian yang disampaikan pada bab sebelumnya mengenai Analisis Penerimaan Bea Balik Nama Kendaraan Bermotor terhadap Penerimaan Pajak Daerah Provinsi DKI Jakarta dengan Penerimaan Bea Balik Nama Kendaraan Bermotor (X) dan Penerimaan Pajak Daerah Provinsi DKI Jakarta (Y) penulis dapat menarik kesimpulan sebagai berikut :

1. Dari hasil uji koefisien korelasi disimpulkan bahwa $\mathrm{H}_{0}$ ditolak dan $\mathrm{H}_{1}$ diterima yang berarti terdapat hubungan yang kuat antara Penerimaan Bea Balik Nama Kendaraan Bermotor terhadap Pajak Daerah Provinsi DKI Jakarta sebesar 0,615 .

2. Dari hasil uji koefisien determinasi disimpulkan adanya pengaruh variabel $\mathrm{X}$ mempengaruhi $\mathrm{Y}$ sebesar $38 \%$ dan $62 \%$ dipengaruhi faktor lain. Dengan nilai signifikan pada sig. $F$ Change $=$ $0,000<0,05$ maka Penerimaan Bea Balik Nama Kendaraan Bermotor berpengaruh terhadap Pajak Daerah Provinsi DKI Jakarta sebesar 0,378.

3. Hasil persamaan regresi linier sederhana yaitu $Y$ $=20,939+0,285 X$ artinya jika Penerimaan Bea Balik Nama Kendaraan Bermotor (X) sebesar Rp 0 maka Penerimaan Pajak Daerah Provinsi DKI Jakarta sebesar Rp 20.939. Sedangkan jika (X) sebesar Rp 1 maka Y mengalami kenaikan 
sebesar Rp 285.

Ada beberapa saran sebagai berikut :

1. Untuk meningkatkan Penerimaan Bea Balik Nama Kendaraan Bermotor sebagai salah satu sumber penerimaan pajak daerah pada Provinsi DKI Jakarta, maka diharapkan pemerintah daerah perlu melakukan sosialisasi kepada masyarakat agar dapat membayarkan Bea Balik Nama Kendaraan Bermotor tepat pada waktunya. Serta memberikan sanksi tegas kepada wajib pajak / pemilik kendaraan bermotor yang belum melunasi kewajiban pajak nya berupa surat teguran yang dikirim ke alamat wajib pajak tersebut.

2. Bagi SAMSAT Jakarta Timur diharapkan untuk lebih memperbaiki sistem pelayanan agar masyarakat tidak bingung dalam pembayaran Bea Balik Nama Kendaraan Bermotor

\section{REFERENSI}

Dyah, E. (2017). Metode Penelitian Kuantitatif (2 ed.). Yogyakarta: Gava Nedia.

Ghozali, I. (2016). Aplikasi Anlisis Multivariate dengan Program IBM SPSS. Yogyakarta: Universitas Diponegoro.

Makaluas, O., \& Tinangon, J. (2016). Analisis Penerimaan Pajak Biaya Balik Nama Kendaraan Bermotor ( Bbnkb) Pada Kantor Dinas Pendapatan Daerah Di Provinsi Sulawesi Utara. 4(2), 13-21.
Mardiasmo. (2016). Perpajakan Edisi Terbaru. Yogyakarta: Penerbit Andi.

Ruma, Z., \& Jamal, A. D. (2013). Pengaruh Pajak Kendaraan Bermotor Terhadap Pendapatan Derah Provinsi Sulawesi Selatan di Kota Makassar. Jurnal Ekonomi, 3, 82-93.

sabil, sabil. (2017). Peranan Penerimaan Pajak Daerah Terhadap Pendapatan Asli Daerah Pada Cabang Pelayanan Dinas Pendapatan Provinsi Wilayah Kabupaten Bogor. Moneter Jurnal Akuntansi dan Keuangan, 4(1), 64-72. Diambil dari http://ejournal.bsi.ac.id/ejurnal/index.php/mon eter/article/view/1673/1410

Siregar. (2017a). Statistik Parametik untuk Penelitian Kuantitatif (1st ed.). jakarta: PT. Bumi Aksara.

Siregar, S. (2017b). Statistik Parametik untuk Penelitian Kuantitatif. jakarta: PT. Bumi Aksara.

Sugiyono. (2016). Metode Penelitian Pendidikan Pendekatan Kuantitatif, Kualitatif, dan R\&D. Bandung: Alfabeta.

Zulfikar, \& Budiantara N. (2014). Manajemen Rist Pendekatan Komputasi Statistika. Yogyakarta: Deepublish.

Peraturan Daerah Nomor 9 Tahun 2010 tentang Bea Balik Nama Kendaraan Bermotor 